industry products until 2016 require the long-term state policy toward agriexport growth. There is a clear trend of increasing food export to the EU countries. However the article highlights some obstacles of mutually beneficial trade expansion. The possibilities of increasing raw materials exports are quite limited. That is why a more diversified export is needed for strengthening the competitive positions of domestic agrifirms on the global food markets. The methods of global competitive positioning can stimulate increased share of high value added processed agricultural goods.

Some shortcomings of oriented on exports and monoculture agricultural production system have been discussed in the article in the context of socio-economic and environmental issues.

The monitoring of agricultural commodities movement trough the export logistics supply chains can reflect the consumers' requirement for quality and safety standards.

Key words: export-oriented activities, agrarian sector of the economy, competitive positioning, the monitoring of logistics supply chains.

DOI 10.31395/2415-8240-2019-95-2-69-79

\title{
TOURISM ATTRACTIVENESS OF CENTRAL UKRAINE
}

\author{
S. V. TYMCHUK, Candidate of Economic Sciences \\ L. M. NESHCHADYM, Candidate of Economic Sciences \\ O. M. SAKOVSKA, Candidate of Economic Sciences \\ Uman National University of Horticulture
}

У статті обтрунтовано вплив туристичної привабливості на розвиток економіки регіону. Був показаний рівень туристичних потоків по регіонах Центральної України. Проаналізовано стан туристичного ринку регіонів Центральної України в частині діючих суб'єктів туризму, видів туризму $i$ иілі поїздок. Доведено важливість розвитку туристичної інфраструктури та демонстрачї туристичної привабливості Центральної України, щцо позначиться на збільшенні дохідної частини як населення, так $і$ місиевих бюджетів в цілому.

Ключові слова: туристична привабливість, туристичний бізнес, туристична поїздка, внутрішній туризм, в'їзний туризм, сервіс. 
Foundation of the problem. Modern globalization processes affect the development of tourism industry in Ukraine. Unsatisfactory indicators of tourism development in some regions of Ukraine against growing level of competition in others require a number of measures for strengthening the role of the state in the tourism area and optimizing the measures to ensure the development of tourism industry.

The development of tourism in different regions of Ukraine has differences. The most popular region of Ukraine for domestic tourism in 2017 was Kyiv region (5 million 684 thousand tourists). Also, the leaders in terms of the number of visits by Ukrainians during the summer season in 2017 were the following regions: Odesa - 1303.4 thousand people (10.4\%), Kherson - 1004.6 thousand people (8\%), Zaporizhzhia - 791.3 thousand people $(6.3 \%)$, Lviv - 721.9 thousand people (5.7\%), Ivano-Frankivsk - 528.6 thousand people (4.2\%), Mykolaiv - 491.1 thousand people ( $3.9 \%)$.

The absence of regions included in the Central Ukraine in the list of tourist leaders of Ukraine is connected with insufficient revealing of their tourism attractiveness. Vinnytsia, Dnipropetrovsk, Kirovohrad, Poltava and Cherkasy regions which have significant tourism potential are in the cultural-and-historical region of the Central Ukraine [4]. There are 580 architectural and urban monuments, 1507 archeological monuments, 1660 historical monuments, and 98 monuments of monumental art are on state register in Vinnytsia region [8]. There is a cradle of Trypillian culture in Cherkasy region which gained the greatest prosperity between 5500 and 2750 B.C., and is one of the main ancient crop cultures of copper age. 9 national and state historical-and-cultural and natural reserves are situated on the territory of the region [4].

Dnipropetrovsk region is known by Ukrainian decorative-and-ornamental folk painting «Petrykivsky rozpys (painting)», which is included in the Representative List of the intangible cultural heritage of humanity of UNESCO [1]. Kirovohrad region is interesting and rich in archaeological terms - fossil monuments were found here, testifying the man's presence on the lands of modern Kirovograd area from the times of the late Paleolithic age [3]. 169 territories and objects of naturaland-reserve fund, mineral springs, about 50 monuments of Scythian-and-Sarmatian age, and a considerable number of historical-and-cultural objects were opened for tourists in Poltava region [8]. This is only a tiny part of tourist facilities that form tourism attractiveness of the Central Ukraine and can be attractive for both domestic and foreign tourists. However, there is still a low level of tourism flows in the categories of domestic and inbound tourism because of improper use of 
existing tourism and reactionary attractions in the regions of the Central Ukraine.

Analysis of recent researches and publications. Scientific works of a number of scientists are dedicated to the study of tourism attractiveness of Ukraine. Thus, Boika M.H. having examined tourism profile of Ukraine for the period of 2006-2009, confirms that the development of national tourism is characterized by structural imperfection, regional deformity and imbalance, which requires more active participation of state structures in the field of sectoral regulation and purposeful policy for tourism appearance at the world level [2, p. 37]. The works of Korol O.D. are dedicated to study of the influence of inbound tourism flows on determining the attractiveness for foreign tourists of one or other country regardless of its size [5, p. 193].

Research methodology. Theoretical and methodological basis of the study were the fundamental provisions of modern economic theory, the work of foreign and domestic scientists, the development of research institutes, the current legislative and regulatory acts in the field of agriculture.

Empirical and theoretical methods, such as dialectical, historical, were used in the research process; comparison, statistical grouping, graphic. In addition, the following methods were used: abstract-logical, generalization and others.

Results of the research. Approximately 10 million domestic tourists were in Ukraine in 2017. However, these data are mediated, because statistics of domestic tourists takes into account only those who are officially registered. Significant decrease in tourism flow (in particular, data from Crimea and occupied territories in Donbass are not taken into account) with gradual growth in next years according to the data of the State Statistics Committee of Ukraine in 2014 was observed. At the same time, only 322 thousand of tourists out of 2.4 million officially registered tourists traveled throughout Ukraine in 2014, the total number of official tourists increased to 2.8 million, and domestic tourists to 477 thousand people in 2017 according to the State Statistics Committee [5].

The level of inbound and outbound tourism is monitored according to the data of the State Border Guard Service of Ukraine, but the level of domestic tourism is counted only by reports of tour operators, hotels, enterprises of the sanatoriumand-resort complex. However, not all of them work legally and provide exact reporting data.

It is difficult to estimate its volume because of the considerable shadowing of the domestic tourism market. One of the possibilities is the use of mediated data. For example, tracking the movements of mobile users. In Ukraine, about 10 million users traveled out of their region and stayed in other areas for more than 
one day, including lodging for the night, meals, etc. in the first half of 2017 [6].

The flow of tourists within the regions of the Central Ukraine is characterized by a low level in comparison with data within Ukraine (Fig. 1).

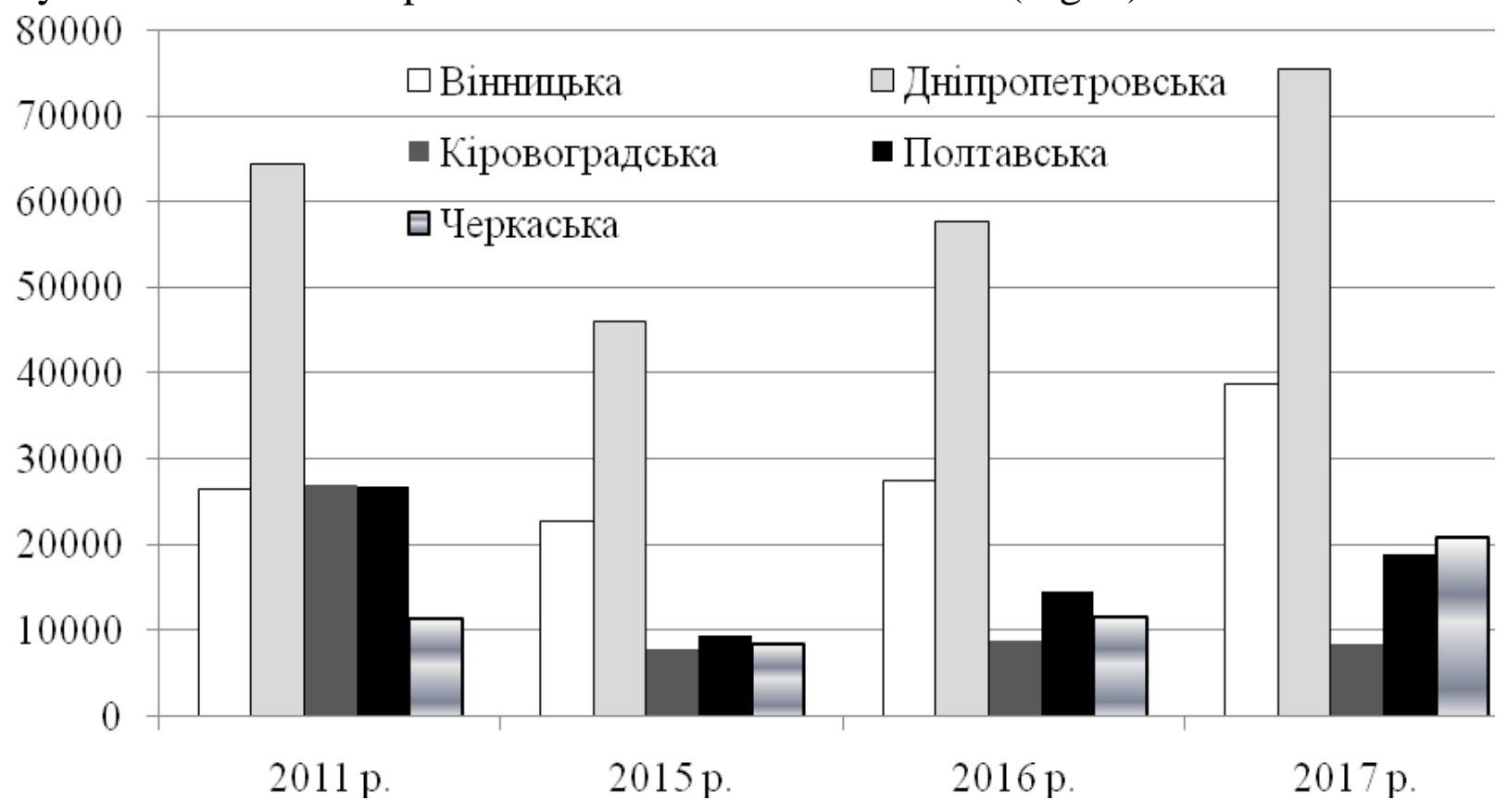

Fig. 1. Dynamics of the number of tourists serviced by tour operators and travel agents in the regions of the Central Ukraine, persons*

* Grouped by the author on the basis on data from the State Statistics Committee of Ukraine

Tourist trips to the territory of the regions of the Central Ukraine in 2017 were done by 2930373 people, however, this index was 18.8 times smaller and was 156119 people in 2011. Dnipropetrovsk region (75526 people in 2017), Vinnytsia region (38634 people in 2017) and Cherkasy region (20953 people in 2017) became the leaders among the regions of the Central Ukraine.

During the reserched period, there was an increase in the number of tourists who wanted to visit tourist attractions of Ukraine (in 1.5 times) from 1840483 people in 2011 to 2806426 people in 2017, respectively. However, specific share of the regions of the Central Ukraine in terms of the tourists number serviced by tour operators and travel agents for the period of 2011-2017 decreased by $2.69 \%$. This index indicates a decrease in the level of interest in tourist attractions in the Central Ukraine. One of the reasons is a poor road condition which significantly reduces the attendance of these regions. The worst road quality was in Cherkasy region according to the results of 2017. In addition, the need to increase the level of advertising on the promotion of tourist attractions of these regions is for increasing the flow of tourists and promotion of tourist product abroad.

Significant role in increasing the flow of tourists to these regions belongs to 
tourism operators who work in the market (Figure 2).

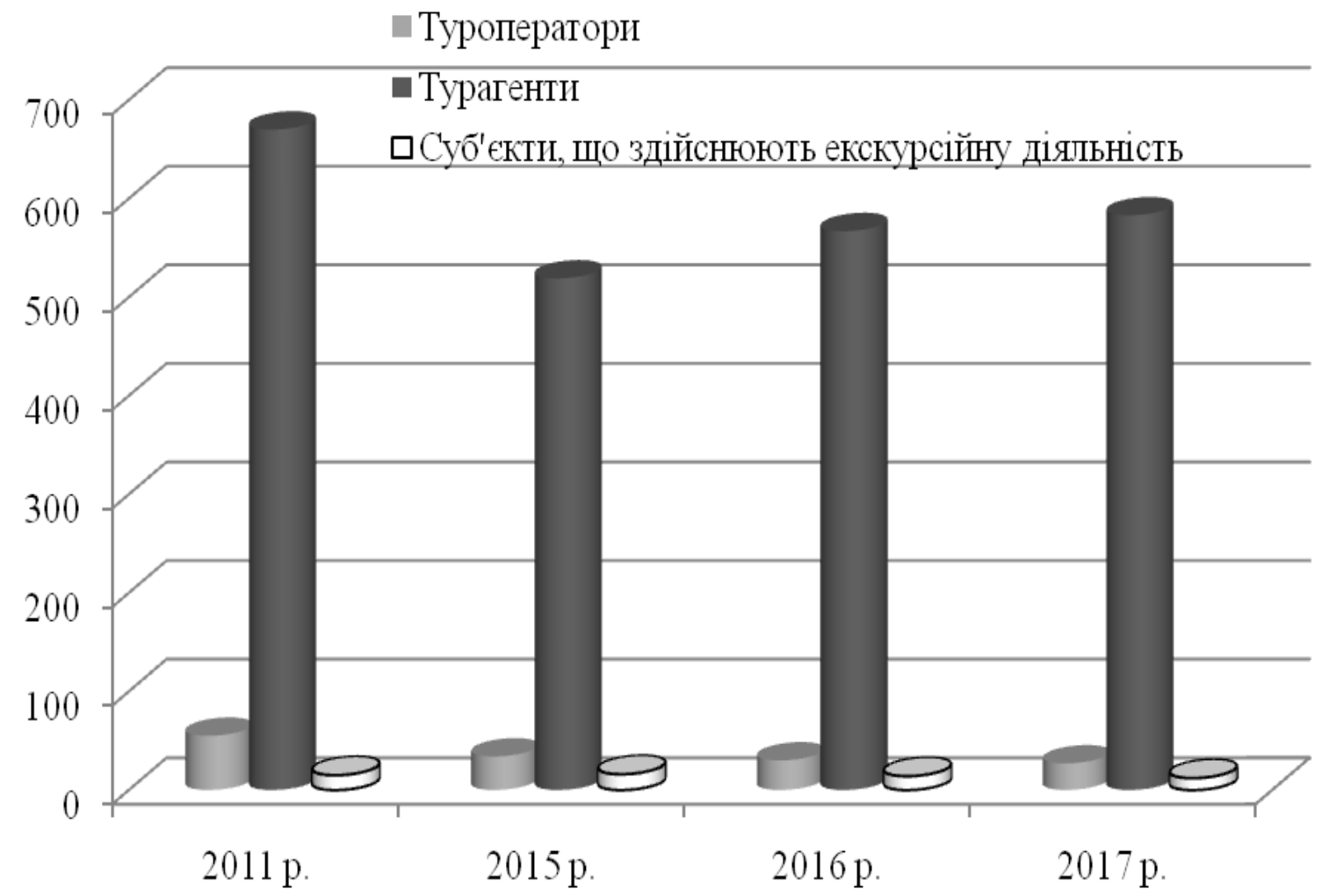

Fig. 2. Dynamics of the number of tourism activity subjects, serving tourists in the regions of the Central Ukraine, units*

* Grouped by the author on the basis on data from the State Statistics Committee of Ukraine

For the period of 2011-2017, the number of tour operators worked in the regions of the Central Ukraine decreased by 28 units, travel agents by 87 units, subjects carrying out excursions by 3 units. In general, the number of tourism activity subjects in the tourist market of the regions of the Central Ukraine decreased by 118 units during the period under research.

There was no one tour operator registered in Poltava and Kirovohrad regions at the end of 2017. There was no one subject carrying out excursion activity registered in Dnipropetrovsk region. The largest number of tour operators and travel agents in 2017 was registered in the Dnipropetrovsk region (12 and 313 units, respectively).

Tour operators and travel agents generally work in the direction of sending Ukrainians abroad. Excursion offices interested in revealing the tourist potential of the region within which they operate can increase the flow of tourists in the regions of the Central Ukraine.

The number of travel passes sold by travel agencies in 2017 indicated the 
decrease in the flow of tourists who traveled within the regions of the Central Ukraine. In general, the official number of sold passes in the regions of the Central Ukraine was 60226 in 2017. From this number, 7041 passes were sold to citizens of Ukraine for travels within Ukraine and only 182 were used by foreigners to travel within Ukraine.

The higher specific share of Ukrainians who traveled within Ukraine was recorded in Kirovohrad region (36.8\%), less number in Cherkasy region (16.5\%) and Dnipropetrovsk (11.9\%) speaking about the total amount of tourist passes sold in 2017 by travel agents. Only 1.5 and $7.6 \%$ were Ukrainian citizens traveling within Ukraine from the total number of trips carried out by travel agents of Vinnytsia and Poltava regions in 2017. Only in Poltava region foreigners made 181 trips which was $2.1 \%$ travelling within Ukraine from the total amount of tourist passes in 2017.

In general, in 2017, a specific share of regions in Central Ukraine was $26.6 \%$ from the total volume of tourist passes sold by travel agents including $11.3 \%$ to the citizens of Ukraine for travelling within Ukraine, $18.4 \%$ for foreigners travelling within Ukraine. Poltava region is preferable among foreign citizens desiring to travel through the Central Ukraine and Kirovohrad region - among Ukrainians.

The purpose and type of tourism chosen by domestic and foreign tourists depend on various factors: having and duration of free time; age, gender, state of health, level of spiritual development, personal tastes and financial well-being; variety of natural conditions of the tourist region and seasonality; availability of certain means of transportation.

The flows of inbound, outbound and domestic tourism in the regions of the Central Ukraine have a similar tendency as in other regions of Ukraine (Table 1). The flow of tourists who left the region was higher than the flow of domestic and foreign tourists like in previous years in the studied region of Ukraine in 2017. In general, tourists who left Ukraine from the central region abroad were 12.2 times more than domestic tourists.

There is a boom of domestic tourism since 2017 till present day. There was an understanding in many settlements that a small town or village might be interesting for tourism, which in turn - the opportunity for the development of the settlement itself. In addition, towns and villages around various reservoirs are becoming a new tourist attraction especially those who are looking for an alternative to the traditional beach holiday on the coast of the Azov and Black Seas.

Since decentralization involves the transfer of responsibilities and resources to the regions, tourism industry itself has all the chances to use resources and 
provide regions with replenishment. Almost all regions of Ukraine identified tourism as one of the key ways of economic development. There is an increase in the level of tourism financing from local budgets and accordingly the level of responsibility for income from this sphere. Tourism is the fastest way to create working places, and hence to receive budget revenues. However, the strategy of tourism development on the local levels must be necessarily connected with the strategy of region development.

Ukrainian domestic tourist is basically independent. $\mathrm{He}$ books accommodation and buys tickets himself and rarely uses the services of specialized companies. He goes in short journeys for 2-3 days several times a year. Domestic tourist becomes more exigent, due to the opening of borders with the EU, he is aware of another level of service and requires appropriate level of service in his country.

Showing of tourist attractiveness of the Central Ukraine depends on the development of transport infrastructure. The flow of visitors depends on the possibility or impossibility to get somewhere. And in this issue, statistics is not yet on the side of the development of tourist potential in Ukraine.

Table 1. Distribution of tourists serviced by travel agencies by travel purpose and tourism types in 2017 in the regions of the Central Ukraine, persons*

\begin{tabular}{|c|c|c|c|c|c|c|c|c|}
\hline \multirow[b]{2}{*}{ Indicator } & \multirow[b]{2}{*}{$\begin{array}{l}\vec{\pi} \\
\ominus \\
\ominus\end{array}$} & \multicolumn{6}{|c|}{ Including by travel purpose } & \multirow[b]{2}{*}{$\begin{array}{c}\text { Inclu } \\
\mathrm{d} \\
\text { ing } \\
\text { child } \\
\text { ren of } \\
0-17\end{array}$} \\
\hline & & 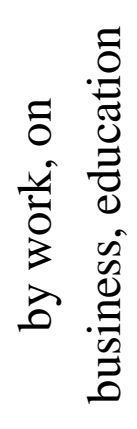 & 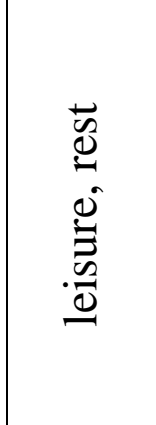 & 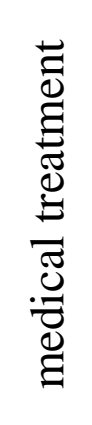 & 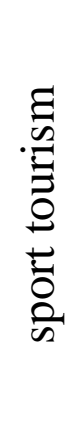 & 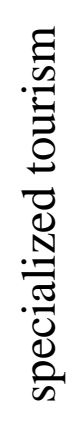 & $\begin{array}{l}\overline{0} \\
\bar{\Xi}\end{array}$ & \\
\hline Domestic tourists & 8387 & 48 & 8151 & 171 & 7 & 0 & 10 & 2060 \\
\hline Inbound foreign tourists & 174 & 22 & 152 & 0 & 0 & 0 & 0 & 0 \\
\hline Outbound tourists & 102562 & 390 & 101931 & 58 & 77 & 0 & 106 & 16105 \\
\hline
\end{tabular}

* Grouped by the author on the basis on data from the State Statistics Committee of Ukraine

Only 10 thousand kilometers of public roads in Ukraine of 170 thousand kilometers do not need to be repaired - that is less than $6 \%$. The worst highways of 
state importance are in Cherkasy, Mykolaiv, Luhansk and Donetsk regions according to the Ministry of Infrastructure.

Tourists have the opportunity to discover picturesque spots and interesting destinations with each their travels, and are concerned that local residents do not understand the benefits of increasing the tourism attractiveness of their place of residence. Communities are usually passive and do not create the necessary infrastructure around them to reveal tourism attractiveness. Locals themselves are interested in opening a small business aimed at tourists. Beautiful nature or historical monuments are not enough, tourists should be able to choose accommodation, meals or transportation. Currently, in most regions of Ukraine there is lack of expert support, dialogue with authorities and confidence among the participants of local and regional tourism markets.

Conclusions. The Central Ukraine needs significant investments in the development of tourism infrastructure. Placement of clear signs to the most famous monuments, roads of excellent quality with recreation areas with all conveniences, places for auto-camps, location of tourist centers, where tourists can get all the necessary information about the region. Accommodation facilities require a European level of service and excellent service to attract domestic and foreign tourists.

\section{Література}

1. Європейський центр екотуризму і агротуризму: веб-сайт. URL: http://www.eceaf.nl (дата звернення: 29.05.2019).

2. Бойко М.Г. Туристична привабливість України: закономірності фомування та орієнтири розвитку. Загальні питання економіки. Інвестищії: практика та досвід. 2009. № 16. С. 34-39.

3. Верменич Я.В. Кіровоградська область. Енциклопедія історії України : у 10 т. Інститут історії України НАН України. - К.: Наукова думка, 2007. Т. 4 : Ка-Ком. С. 331.

4. Tymchuk S. V., Neshchadym L. M. Cluster analysis of the effectiveness of tourist companies in Ukraine. Науковий вісник Ужгородського наиіонального університету. Серія: Міжнародні економічні відносини та світове господарство. Випуск 15, частина 2. 2017. С. 136-141.

5. Король О.Д. В'їзні туристичні потоки та іноземна туристична привабливість (атрактивність). Науковий вісник Херсонського державного університету. Випуск 7. 2017. С. 192-202.

6. Нещадим Л.М.,Тимчук С.В. Інноваційні методи економічного 
аналізу діяльності туристичних підприємств в Україні. Науково-виробничий журнал «Бізнес-навігатор», випуск 2(41). 2017. С. 84-88.

7. Кошляк А. Туризм і децентралізація: як українці відкривають для себе країну.

URL: доступу: https://lb.ua/economics/2018/11/03/411461_turizm_i_ detsentralizatsiya_yak.html

8. Тимчук С.В. Підприємництво на туристичному ринку центральної України. Інфраструктура ринку. Вип. 25. 2018 р. С. 562-567.

\section{References}

1. European Center for Ecotourism and Agro-tourism: Web site. URL: http://www.eceaf.nl (accessed: 29 May 2019).

2. Boiko M.H. (2009) Tourism attractiveness of Ukraine: regularities of formation and orientation points of development. General issues of economics. Investments: practice and experience, no. 16, pp: 34-39. (in Ukrainian).

3. Vermenych Ya.V. (2007) Kirovohrad region. Encyclopaedia of Ukrainian history: in $10 \mathrm{v}$. Institute of History of Ukraine of National Academy of Sciences of Ukraine. - K.: Naukova dumka, vol. 4, p: 331. (in Ukrainian).

4. Tymchuk S.V., Neshchadym L.M. (2017) Cluster analysis of effectiveness of tourist companies in Ukraine. Scientific herald of Uzhgorod National University. Series: International Economic Relations and World Economy, Issue 15, part 2. pp: 136-141. (in Ukrainian).

5. Korol O.D. (2017) Inbound tourism flows and foreign tourism attractiveness. Scientific bulletin of Kherson State University, Issue 7, pp: 192202. (in Ukrainian).

6. Neshchadym L.M., Tymchuk S.V. (2017) Innovative methods of economic analysis of the activity of tourism enterprises in Ukraine. Scientific and Production Magazine «Business Navigator», issue 2 (41), pp: 84-88. (in Ukrainian).

7. Koshliak A. (2018) Tourism and decetralization: how Ukrainians reveal a country for themselves: URL : https://lb.ua/economics//11/03/411461_turizm_i_ detsentralizatsiya_yak.html. (accessed: 29 May 2019).

8. Tymchuk S.V. (2018) Enterprise on the tourist market of central Ukraine. Market infrastructure. Issue. 25. pp: 562-567. (in Ukrainian). 


\section{Аннотация}

\section{Тимчук С.В., Нещцдим Л.М., Саковська О.М.}

\section{Туристическая привлекательность центральной Украины}

В статье обосновано влияние туристической привлекательности на развитие экономики региона. Показан уровень туристических потоков по регионам Центральной Украиныл. Проанализировано состояние туристического рынка регионов Центральной Украины в части действующих субъектов туризма, видов туризма и цุели поездок. Доказана важность развития туристической инфраструктурь и демонстрачии туристической привлекательности Центральной Украинь, что скажется на увеличении доходной части как населения, так и местных бюджетов в целом.

Современные процессы глобализации влияют на развитие туристической отрасли Украиньл. Неудовлетворительные показатели развития туризма в отдельных регионах Украины требуют ряда мер по усилению роли государства в туристической сфере и оптимизачии мероприятий по обеспечению развития туристической отрасли.

Установлено, что уровень въездного и выездного туризма отслеживается по данным пограничной службы Украины, но уровень внутреннего туризма учитывается исключительно по отчетам туроператоров, гостинии, предприятий санаторнокурортного комплекса. Однако не все из них работают легально и подают точные отчетные данные. Именно в связи со значительной тенизачией внутреннего туристического рынка, оценить его объем сложно. Одной из возможностей является использование косвенных данных. Например, отслеживая перемещениями абонентов мобильной связи.

С 2017 г. и до сих пор наблюдается бум туризма. Во многих населенных пунктах появилось понимание, что небольшой городок или деревня может быть интересным для туризма, а это в свою очередь - возможность для развития самого населенного пункта. Кроме того, города и села у различных водоемов становятся новой приманкой для туристов. Особенно тех, кто ищет альтернативу традиционному пляжному отдыху на побережье Азовского и Черного морей.

Поскольку децентрализачия предусматривает передачу ответственности и ресурсов регионам, сама туристическая отрасль имеет все шансы использовать ресурсы и обеспечить пополнение регионов. Почти все регионы Украины определили туризм как один из ключевых путей экономического развития. Увеличивается уровень финансирования туризма из местных бюджетов и соответственно уровень ответственности за доходы от этой сферы. Туризм является самым быстрым способом создания рабочих мест и, следовательно, получения доходов бюджета. Однако стратегия развития туризма на местном уровне должно быть обязательно связана со стратегией развития региона.

Ключевые слова: туристическая привлекательность, туристический бизнес, туристическая поездка, внутренний туризм, въездной туризм, сервис. 


\section{Annotation}

\section{Tymchuk S. V., Neshchadym l. M., Sakovska O.M.}

\section{Tourism attractiveness of central Ukraine}

The article substantiated the influence of tourism attractiveness on the development of the region's economy. The level of tourism flows concerning the regions of the Central Ukraine was deternimed. The state of the tourism market of the regions of the Central Ukraine in the part of functioning tourism subjects, types of tourism and the purpose of travels was analyzed. The importance of tourism infrastructure development and showing of tourism attractiveness of the Central Ukraine, that will affect the increase of income part of both the population and local budgets in general was proved.

Modern processes of globalization influence the development of the tourism industry in Ukraine. Unsatisfactory indicators of tourism development in some regions of Ukraine require a number of measures to strengthen the role of the state in the tourism sector and to optimize measures to ensure the development of tourism industry.

It is established that the level of inbound and outbound tourism is monitored according to the data of the border service of Ukraine, but the level of domestic tourism is calculated solely according to the reports of tour operators, hotels, enterprises of the sanatorium and resort complex. However, not all of them work legally and provide accurate reporting. It is difficult to estimate its volume due to the significant shadowing of the domestic tourism market. One possibility is to use indirect data. For example, tracking the movements of mobile subscribers.

From 2017 to the present, there is a boom in domestic tourism. In many settlements it became clear that a small town or village can be interesting for tourism, which in turn is an opportunity for the development of the settlement itself. In addition, towns and villages near various reservoirs are becoming a new attraction for tourists. Especially those looking for an alternative to a traditional beach holiday on the coast of the Azov and Black Seas.

As decentralization involves the transfer of responsibilities and resources to the regions, the tourism industry itself has every chance to use resources and to replenish the regions. Almost all regions of Ukraine identified tourism as one of the key ways of economic development. The level of financing of tourism from local budgets increases and the level of responsibility for revenues from this sphere is increasing. Tourism is the fastest way to create jobs and, consequently, to generate budget revenues. However, the strategy of tourism development at the local level must be necessarily linked to the development strategy of the region.

Key words: tourism attractiveness, tourism business, tourist trip, domestic tourism, inbound tourism, service. 